\title{
Characterization and reactivity of 11-molybdo-1-vanadophosphoric acid catalyst supported on zirconia for dehydration of glycerol to acrolein
}

\author{
BALAGA VISWANADHAM, AMIRINENI SRIKANTH and KOMANDUR V R CHARY* \\ Catalysis Division, Indian Institute of Chemical Technology, Hyderabad 500 007, India \\ e-mail: kvrchary@iict.res.in
}

MS received 18 September 2013; revised 27 December 2013; accepted 30 December 2013

\begin{abstract}
A series of vanadium-substituted phosphomolybdic acid (HPA) catalysts supported on zirconia were prepared by impregnation method with varying the HPA active phase content from 10 to $50 \mathrm{wt} \%$ on the support. The calcined catalysts were characterized by X-ray diffraction, Raman spectroscopy, temperatureprogrammed desorption of $\mathrm{NH}_{3}$, FT-IR spectra of pyridine adsorption and surface area measurements. XRD results suggest that the active phase of heteropolyacid is present in a highly dispersed state at lower loadings and as a crystalline phase at higher HPA loadings and these findings are well-supported by the results of FT-IR and Raman spectra. Calcination of the samples did not affect the Keggin ion structure of HPA. The ammonia TPD results suggest that acidity of the catalysts was found to increase with increase of HPA loading up to $40 \mathrm{wt} \%$ and decreases at higher loadings. FT-IR spectra of pyridine adsorption show that the Brønsted acidic sites increase with increase of HPA loadings up to $40 \mathrm{wt} \%$ catalyst. However, Lewis acid sites decrease with increase of HPA loading. Catalytic properties were evaluated during vapour phase dehydration of glycerol to acrolein. The catalyst with $40 \mathrm{wt} \%$ HPA has exhibited excellent selectivity towards acrolein formation with complete conversion of glycerol at $225^{\circ} \mathrm{C}$ under atmospheric pressure. Catalytic performances during dehydration of glycerol are well-correlated with acidity of the catalysts.
\end{abstract}

Keywords. $\mathrm{H}_{4} \mathrm{PMo}_{11} \mathrm{VO}_{40} / \mathrm{ZrO}_{2}$; acidity; Raman; glycerol dehydration; acrolein.

\section{Introduction}

Exploitation of glycerol for the production of valueadded fine chemical intermediates is a topic of enormous interest in the recent past because glycerol is a by-product formed in huge amounts during the production of biodiesel from renewable sources. Various processes such as hydrogenolysis, dehydration, acetylation, etc., have been investigated for converting glycerol into value-added products. Among these processes, dehydration of glycerol is one of the interesting and challenging route and to produce acrolein in the presence of solid acid catalysts. Acrolein is an important and versatile chemical intermediate used in many industrial applications and it is the starting material for the production of acrylic acid, acrylic acid ester, glutaraldehyde and methionine. ${ }^{1-5}$ This process is widely investigated by many researchers to convert glycerol into value-added chemicals via environmentally benign catalytic pathways. In general, dehydration of glycerol

\footnotetext{
*For correspondence
}

to acrolein is accompanied by side reactions leading to the formation of some by-products such as hydroxy propanone, propanaldehyde, acetaldehyde, acetone and adducts of acrolein to form polyaromatic compounds. This leads to the formation of coke over the active sites and causes deactivation of the catalyst. However the presence of these by-products with acrolein necessitates high recovery cost for separation and purification of acrolein. Various solid acid catalysts including sulphates, phosphates, zeolites, heteropolyacids and solid phosphoric acid (SPA) have been tested for the dehydration of glycerol in either gaseous or liquid phase. ${ }^{6-21}$ Glycerol is usually produced as a mixture with water. Usage of glycerol with water is advantageous over pure glycerol for the production of acrolein and also a solid acid catalyst with a high redox property of catalyst would be beneficial for obtaining the better catalytic activities which minimizes the coke formation.

Usage of $\mathrm{ZrO}_{2}{ }^{22,23}$ as a catalyst support has several advantages over other conventional oxide supports such as alumina, silica and titania. Advantages of using zirconia as a support include: (i) interacts strongly with the active phase, (ii) possesses high thermal stability and more chemically inert than the 
conventional supported oxides and (iii) it has acidic and redox properties. Zirconia-supported heteropolyacids have high surface area and high thermal stability. By varying the amount of $\mathrm{H}_{4} \mathrm{PMo}_{11} \mathrm{VO}_{40}$ (HPA) on the support leads to an enhancement of the catalytic performance. ${ }^{21,24-26}$ Design of solid acid catalysts containing heteropolyacids is one of the key technologies to establish environment-friendly catalytic processes. The bulk phosphomolybdic acid with primary Keggin unit is well-recognized as the oxidation and also solid acid catalyst in which the redox and acidic functionalities can be tuned by substitution of vanadium metal in the Keggin units. Synthesis of vanadium-containing phosphomolybdic acid is found to be an interesting and promising heteropolyacid catalyst wherein, the molybdenum metal is partially replaced by vanadium metal. Vanadiumcontaining phosphomolybdic acid possesses positive reduction potentials compared to pure phosphomolybdic acid and enhances the redox properties. Thus, incorporation of $\mathrm{V}$ into the structure of phosphomolybdic acid (PMA) enhances the catalytic performance (acid and redox catalysts). ${ }^{27,28}$ Vanadium-containing HPAs have shown excellent redox properties because substitution of vanadium stabilizes the LUMOs..$^{29,30}$ Vanadiumcontaining HPA catalysts are the basic components of several oxidative and acidic reactions in homogenous and heterogeneous catalysis. ${ }^{26,31-35}$

In the present study, we report dehydration of glycerol to acrolein over a series of vanadium-containing HPA catalyst as an active phase supported on zirconia. The aim of this investigation is to study the effect of HPA loading on zirconia during the vapour phase dehydration glycerol under mild reaction conditions. We also report the comparison of different supports with HPA as an active phase on the catalytic properties during dehydration of glycerol. The purpose of this study is to estimate acidity of vanadium-substituted phosphomolybdic acid supported on zirconia as a function of HPA loading and to identify the structural changes of HPA with increase of active phase loading and also to understand the relation between selectivity and acidic sites. The calcined catalysts are characterized by XRD, BET surface area, FT-IR, Raman, TPD of $\mathrm{NH}_{3}$ and FT-IR of pyridine adsorbed samples to obtain the structural and acidic properties of the active species and relate it to the catalytic functionalities during vapour phase dehydration of glycerol. Product distributions during dehydration of glycerol were investigated as a function of different reaction variables such as the effect of active phase loading, reaction temperature, time on stream and the nature of the support.

\section{Experimental}

\subsection{Catalyst preparation}

2.1a Synthesis of $\mathrm{ZrO}_{2}$ support: Various metal oxides employed during the catalysts preparation are vanadium(V) oxide, zirconium(IV) isopropoxide and titanium(IV) isopropoxide supplied by Aldrich. Molybdenum(VI) oxide procured from Fluka Chemie and phosphoric acid from S D Fine-Chem. Ltd. Aluminum oxide supplied by Engelhard Corporation. Zirconia support was prepared using zirconium(IV) isopropoxide as a precursor. About $40 \mathrm{~g}$ of zirconium(IV) isopropoxide was hydrolysed by slow addition of $20 \mathrm{ml}$ of distilled water until the formation of a white precipitate. This precipitate was filtered and washed with distilled water and then dried at $100^{\circ} \mathrm{C}$ for $10 \mathrm{~h}$. The solid product of zirconium(IV) hydroxide is calcined at $500^{\circ} \mathrm{C}$ for $5 \mathrm{~h}$. Titania support was also prepared by using titanium(IV) isopropoxide as a precursor by similar procedure.

$2.1 \mathrm{~b}$ Synthesis of $\mathrm{H}_{4} \mathrm{PMo}_{11} \mathrm{VO}_{40} / \mathrm{ZrO}_{2}$ catalyst: Preparation of $\mathrm{H}_{4} \mathrm{PMo}_{11} \mathrm{VO}_{40}$ has been reported elsewhere. ${ }^{26} \mathrm{H}_{4} \mathrm{PMo}_{11} \mathrm{VO}_{40}$ is prepared by adding requisite quantities of $\mathrm{MoO}_{3}, \mathrm{~V}_{2} \mathrm{O}_{5}$ and $\mathrm{H}_{3} \mathrm{PO}_{4}$ solutions to distilled water and refluxed at $100^{\circ} \mathrm{C}$. The resulting solid is dried at $60^{\circ} \mathrm{C}$ for $16 \mathrm{~h}$. A series of $\mathrm{H}_{4} \mathrm{PMo}_{11} \mathrm{VO}_{40}$ catalysts with $\mathrm{H}_{4} \mathrm{PMo}_{11} \mathrm{VO}_{40}$ loadings ranging from 10$50 \mathrm{wt} \%$ supported on $\mathrm{ZrO}_{2}$ was prepared by the impregnation method. A required amount of HPA was dissolved in distilled water, and then $\mathrm{ZrO}_{2}$ was added to the above solution. The resultant solution was stirred at room temperature for $5 \mathrm{~h}$. The catalysts were subsequently dried at $110^{\circ} \mathrm{C}$ for $10 \mathrm{~h}$ and calcined in air at $250^{\circ} \mathrm{C}$ for $4 \mathrm{~h}$.

\subsection{Catalyst characterization}

2.2a X-ray diffraction: X-ray powder diffraction patterns of the samples were obtained with a model: D8 Diffractometer (Advance, Bruker, Germany), using $\mathrm{Cu}$ $\mathrm{K} \alpha$ radiation $(1.5406 \AA)$ at $40 \mathrm{kV}$ and $30 \mathrm{~mA}$. Measurements were recorded in steps of $0.045^{\circ}$ with a count time of $0.5 \mathrm{~s}$ in the range of $2-65^{\circ}$.

2.2b BET surface area: Specific surface area of the catalysts were estimated using $\mathrm{N}_{2}$ adsorption isotherms at $-196^{\circ} \mathrm{C}$ by the multipoint BET method taking $0.162 \mathrm{~nm}^{2}$ as its cross-sectional area using Autosorb 1 (Quantachrome instruments).

2.2c Raman spectroscopy: Raman spectra of the catalyst samples were collected with a Horbia-Jobin Yvon LabRam-HR spectrometer equipped with a 
confocal microscope, 2400/900 grooves/mm gratings, and a notch filter. Visible laser excitation at $532 \mathrm{~nm}$ (visible/green) is supplied by a Yag doubled diode pumped Laser $(20 \mathrm{~mW})$. Scattered photons were dried and focused on to a single-stage monochromator and measured with a UV-sensitive LN2-cooled CCD detector (Horbia-Jobin Yvon CCD-3000 V).

\section{2d Temperature-programmed desorption of ammo-}

nia: Temperature-programmed desorption (TPD) studies of $\mathrm{NH}_{3}$ were conducted on Auto Chem 2910 (Micromeritics, USA) instrument. In a typical experiment, ca. $100 \mathrm{mg}$ of calcined $\mathrm{H}_{4} \mathrm{PMo}_{11} \mathrm{VO}_{40} / \mathrm{ZrO}_{2}$ sample is taken in a U-shaped quartz cell. The catalyst sample is packed in one arm of the sample tube on a quartz wool bed. Prior to TPD studies, the catalyst sample is pre-treated by passing high purity helium $(50 \mathrm{ml} / \mathrm{min})$ at $200^{\circ} \mathrm{C}$ for $1 \mathrm{~h}$. After pre-treatment, the sample was saturated by passing $(50 \mathrm{ml} / \mathrm{min})$ high purity anhydrous ammonia at $80^{\circ} \mathrm{C}$ for $1 \mathrm{~h}$ and subsequently flushed with $\mathrm{He}$ flow $(50 \mathrm{ml} / \mathrm{min})$ at $150^{\circ} \mathrm{C}$ for $1 \mathrm{~h}$ to remove physisorbed ammonia. TPD analysis was carried out from ambient temperature to $600^{\circ} \mathrm{C}$ at a heating rate of $10^{\circ} \mathrm{C} / \mathrm{min}$. Ammonia concentration in the effluent stream was monitored with thermal conductivity detector, and the area under the peak was integrated using the software GRAMS/32 to determine the amount of desorbed ammonia.

2.2e Fourier trans infrared spectroscopy: FT-IR spectra of the catalysts were recorded on a IR (Model: GC-FT-IR Nicolet 670) spectrometer by $\mathrm{KBr}$ disc method at room temperature. Ex situ experiments of FTIR spectra of pyridine adsorbed samples were carried out to determine the nature of acidity (Brønsted and Lewis acid sites). Before recording the IR spectra, pyridine adsorption experiments were carried out by placing a drop of pyridine on $10 \mathrm{mg}$ of the HPA sample followed by evacuation in air for $1 \mathrm{~h}$ at room temperature to remove reversibly adsorbed pyridine on the surface of the catalyst. ${ }^{35}$

\subsection{Dehydration of glycerol}

Vapour phase dehydration reaction of glycerol was carried out at $200-250^{\circ} \mathrm{C}$ under atmospheric pressure in a vertical fixed-bed pyrex glass reactor of $36 \mathrm{~cm}$ length and $0.5 \mathrm{~cm}$ internal diameter with a catalyst bed set at the middle of reactor. The reactor is placed in an electrically heated furnace. Temperature was controlled by a thermocouple which is located near the catalyst bed and $\mathrm{N}_{2}$ gas was used as a carrier gas. The glass reactor was packed with $0.3 \mathrm{~g}$ of catalyst, and above the catalyst bed, the reactor was packed with ceramic beads which serve as pre-heater zone to increase evaporation of liquid glycerol feed before reaching the catalyst bed. The catalyst was pretreated with $\mathrm{N}_{2}$ gas at $60 \mathrm{ml} / \mathrm{min}$ at same reaction temperature for $1 \mathrm{~h}$. An aqueous glycerol $(10 \mathrm{wt} \%)$ solution $(0.5 \mathrm{ml} / \mathrm{h})$ was fed from the top of the reactor through inlet in a flow of $\mathrm{N}_{2}$ gas at $6 \mathrm{ml} / \mathrm{min}$. Reaction products were collected in a cold trap every hour and were analysed by Gas Chromatograph (Shimadzu GC-2014) equipped with flame ionization detector using DB-wax 123-7033 capillary column and methanol as internal standard. Glycerol conversion and product selectivities are calculated by the following equations.

Glycerol conversion $(\%)=\frac{\text { Moles of glycerol reacted }}{\text { Moles of glycerol fed }} \times 100$

Product selectivity $(\mathrm{mol} \%)=\frac{\text { Moles of carbon in a product defined }}{\text { Moles of carbon in glycerol reacted }}$ $\times 100$

\section{Results and discussion}

\subsection{Characterization techniques}

3.1a X-ray diffraction: X-ray diffraction patterns of the pure zirconia and zirconia-supported $\mathrm{H}_{4} \mathrm{PMo}_{11} \mathrm{VO}_{40}$ catalysts are presented in figure 1 . In general, $\mathrm{ZrO}_{2}$ exists in three crystallographic polymorphs namely monoclinic, tetragonal and cubic. $\mathrm{X}$-ray diffraction pattern of pure zirconia used in the present study was crystalline in nature and having both monoclinic and tetragonal phases. Sharp X-ray diffraction lines at $d=3.19,3.73$ and $2.86 \AA$ are due to $\mathrm{m}-\mathrm{ZrO}_{2}$ and $\mathrm{X}$-ray diffraction lines at $d=2.98$ and $1.85 \AA$ are due to the $\mathrm{t}-\mathrm{ZrO}_{2} \cdot{ }^{33}$ As HPA loading increases on the zirconia support, intensity of X-ray diffractions peaks at $2 \theta=6.8^{\circ}, 10.9^{\circ}, 27.5^{\circ}$ and $33.5^{\circ}$ also increase. This result clearly suggests formation of Keggin ion structure of heteropolyacid (HPA) on zirconia support. At lower HPA loadings, the above XRD peaks are absent suggesting that HPA is well-dispersed on the zirconia support. However, at lower loadings, the presence of HPA crystalline species of a size less than $4 \mathrm{~nm}$ which is beyond the detection limit of powder $\mathrm{X}$-ray diffraction technique, cannot be ruled out.

3.1b BET surface area: Surface areas of the $\mathrm{ZrO}_{2}$ supported HPA catalysts are presented in table 1 . Specific surface area of the catalysts decreases with HPA loading. This decline of surface area with increasing of HPA loading is due to blocking the pores of the support by crystalline phase of HPA. 


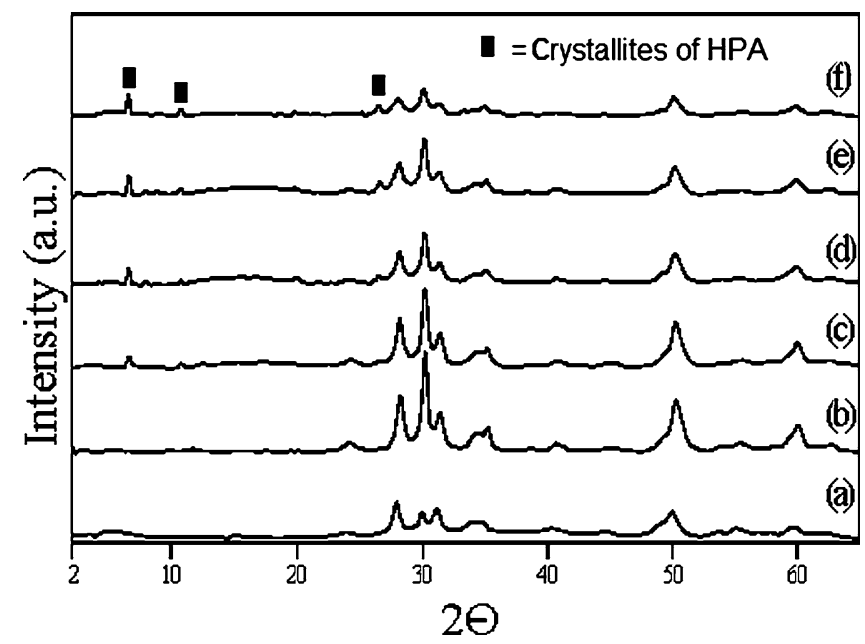

Figure 1. X-ray diffraction patterns of various wt\% of $\mathrm{H}_{4} \mathrm{PMo}_{11} \mathrm{VO}_{40} / \mathrm{ZrO}_{2}$ catalysts. (a) Pure $\mathrm{ZrO}_{2}$, (b) 10 , (c) 20, (d) 30, (e) 40 and (f) 50 .

3.1c FT-IR spectroscopy: Figure 2 shows FT-IR spectra of different wt $\%$ of $\mathrm{H}_{4} \mathrm{PMo}_{11} \mathrm{VO}_{40}$ loadings supported on $\mathrm{ZrO}_{2}$ recorded in the range of 1100 $700 \mathrm{~cm}^{-1}$. Pure HPA material was also characterized by FT-IR spectroscopy for better comparison of results and it is also shown in figure 2 (inset). Figure 2 shows that all the samples exhibit four well-defined infrared bands in the range of $1100-700 \mathrm{~cm}^{-1}$ at $1056 \mathrm{~cm}^{-1}$, $950 \mathrm{~cm}^{-1}, 857$, and $790 \mathrm{~cm}^{-1} \cdot 36,37$ These IR bands are attributed to vibrational bands of $\mathrm{P}-\mathrm{O}, \mathrm{Mo}-\mathrm{O}, \mathrm{Mo}-$ $\mathrm{O}_{\mathrm{c}}-\mathrm{Mo}\left(\mathrm{O}_{\mathrm{c}}=\right.$ corner sharing oxygen $)$ and $\mathrm{Mo}-\mathrm{O}_{\mathrm{e}}-\mathrm{Mo}$ $\left(\mathrm{O}_{\mathrm{e}}=\right.$ edge sharing oxygen $)$, respectively. It can be seen from figure 2 that the intensity of these four skeletal vibrations of Keggin ion are found to increase with HPA loading on $\mathrm{ZrO}_{2}$ support. At higher HPA loading (50 wt \%), IR bands of Mo-O - Mo and Mo- $\mathrm{O}_{\mathrm{e}}-\mathrm{Mo}$ are clearly observed suggesting the formation of bulk-like $\mathrm{HPA}$ on the $\mathrm{ZrO}_{2}$ support. Characteristic bands of four skeletal vibrations observed in all the materials confirm that primary Keggin ion structure is retained on

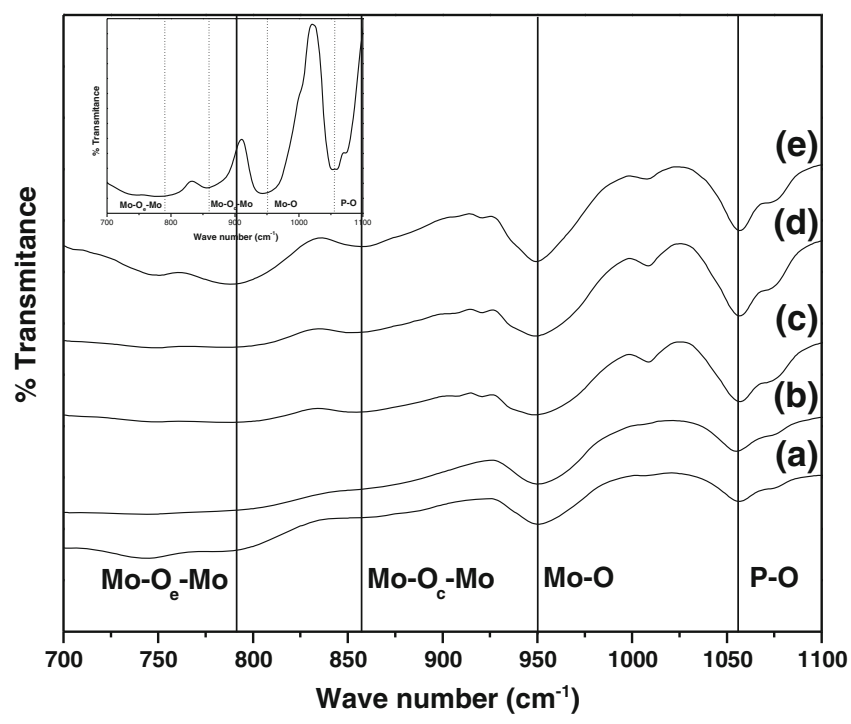

Figure 2. FT-IR spectra of various wt $\%$ of $\mathrm{H}_{4} \mathrm{PMo}_{11} \mathrm{VO}_{40} /$ $\mathrm{ZrO}_{2}$ catalysts. (a) 10, (b) 20, (c) 30, (d) 40 and (e) 50 .

zirconia support. FTIR results are good agreement with XRD studies.

3.1d Raman spectroscopy: Raman spectra of tetragonal zirconia is characterized by bands at 263, 302, 534 and $645 \mathrm{~cm}^{-1}$ However, monoclinic zirconia show Raman bands with frequencies at 331, 374, 476, 530, 539 and $616 \mathrm{~cm}^{-1}$. $^{38}$ Laser Raman spectra of pure $\mathrm{H}_{4} \mathrm{PMo}_{11} \mathrm{VO}_{40}$ and various loadings of $\mathrm{H}_{4} \mathrm{PMo}_{11} \mathrm{VO}_{40}$ supported on $\mathrm{ZrO}_{2}$ is shown in figures 3 and 4, respectively. Laser Raman spectra of pure $\mathrm{H}_{4} \mathrm{PMo}_{11} \mathrm{VO}_{40}$ and various loadings of $\mathrm{HPA} / \mathrm{ZrO}_{2}$ catalysts showed Raman bands at 1000, 842, 676 and $300 \mathrm{~cm}^{-1}$. These Raman bands are assigned to frequencies of $v_{\mathrm{s}}\left(\mathrm{Mo}-\mathrm{O}_{\mathrm{t}}\right)$, $v_{\text {as }}\left(\mathrm{Mo}-\mathrm{O}_{\mathrm{t}}\right), v_{s}\left(\mathrm{Mo}-\mathrm{O}_{\mathrm{c}}-\mathrm{Mo}\right)$ and $v_{\mathrm{s}}\left(\mathrm{Mo}-\mathrm{O}_{\mathrm{a}}\right)$, respectively. As the HPA loading increases from 10 to $50 \mathrm{wt} \%$ on zirconia support, intensity of aforementioned Raman bands increase indicating that the Keggin structure of

Table 1. Results of BET surface area and TPD-NH $\mathrm{NH}_{3}$ of $\mathrm{H}_{4} \mathrm{PMo}_{11} \mathrm{VO}_{40} / \mathrm{ZrO}_{2}$ catalysts.

\begin{tabular}{|c|c|c|c|c|c|}
\hline \multirow[b]{2}{*}{ HPA loading } & \multirow[b]{2}{*}{ BET surface area $\left(\mathrm{m}^{2} / \mathrm{g}\right)$} & \multicolumn{3}{|c|}{$\mathrm{NH}_{3}$ uptake $(\mathrm{mmol} / \mathrm{g})$} & \multirow[b]{2}{*}{ Total $\mathrm{NH}_{3}$ uptake $(\mathrm{mmol} / \mathrm{g})$} \\
\hline & & $\mathrm{Weak}^{\mathrm{a}}$ & Moderate ${ }^{b}$ & Strong $^{\mathrm{c}}$ & \\
\hline 10 & 56 & 0.252 & 0.230 & 0.114 & 0.596 \\
\hline 20 & 42 & 0.298 & 0.524 & 0.078 & 0.900 \\
\hline 30 & 28 & 0.340 & 2.563 & - & 2.903 \\
\hline 40 & 19 & 0.493 & 4.850 & - & 5.343 \\
\hline 50 & 8 & 0.696 & 3.512 & - & 4.208 \\
\hline
\end{tabular}

${ }^{\mathrm{a}}$ Weak acidic sites $=150^{\circ}-300^{\circ} \mathrm{C}$

${ }^{\mathrm{b}}$ Moderate acidic sites $=300^{\circ}-450^{\circ} \mathrm{C}$

${ }^{\mathrm{c}}$ Strong acidic sites $=450^{\circ}-550^{\circ} \mathrm{C}$ 


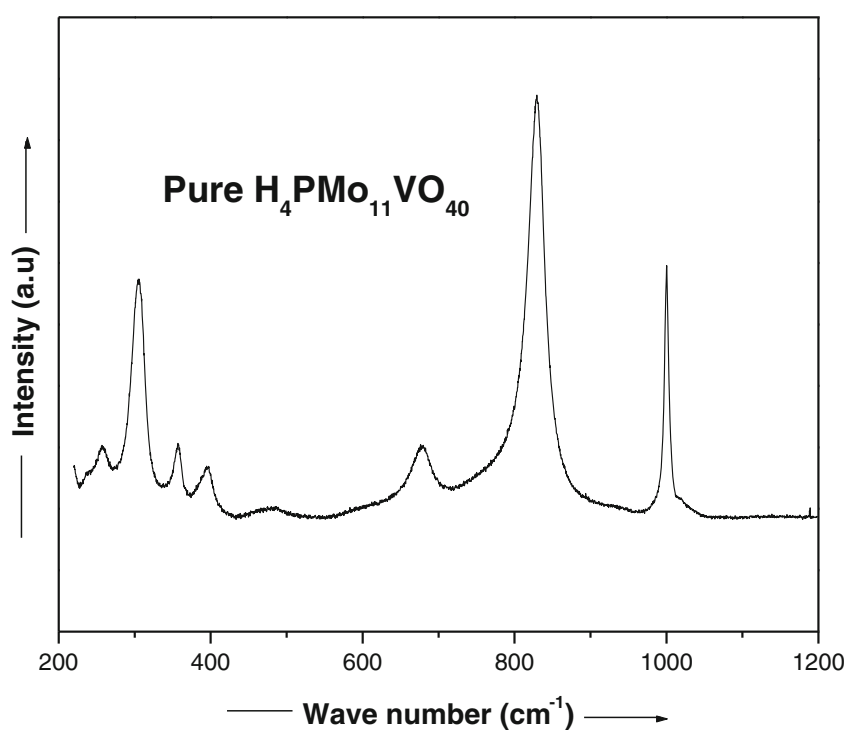

Figure 3. Raman spectra of pure $\mathrm{H}_{4} \mathrm{PMo}_{11} \mathrm{VO}_{40}$ acid.

heteropolyacid remains intact in all the calcined samples. However, the sample with $40 \mathrm{wt} \%$ HPA showed clear characteristic Keggin ion band at $1000 \mathrm{~cm}^{-1}$ and this band is shifted to $1005 \mathrm{~cm}^{-1}$ at higher loadings. Stretching frequencies of $v_{\mathrm{as}}\left(\mathrm{Mo}-\mathrm{O}_{\mathrm{t}}\right)$ and $v_{\mathrm{s}}\left(\mathrm{Mo}-\mathrm{O}_{\mathrm{a}}\right)$ observed clearly at 846 and $300 \mathrm{~cm}^{-1}$ at higher loading

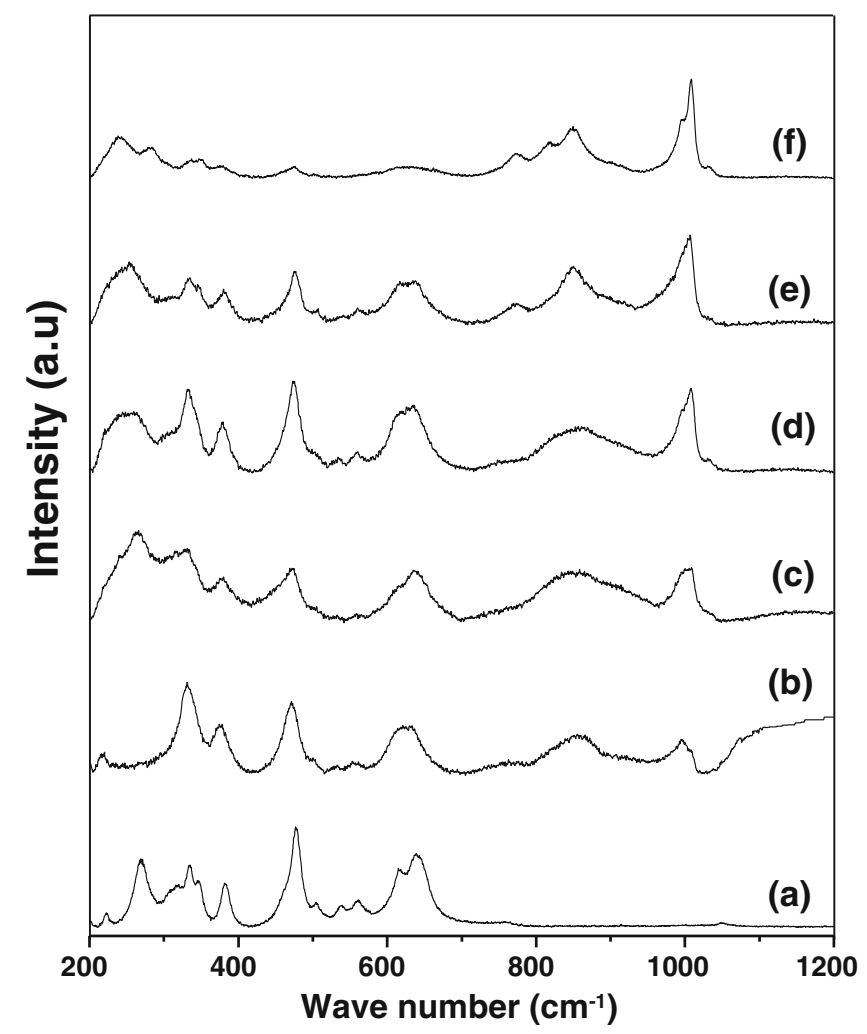

Figure 4. Raman spectra of various wt $\%$ of $\mathrm{H}_{4} \mathrm{PMo}_{11} \mathrm{VO}_{40} /$ $\mathrm{ZrO}_{2}$ catalysts. (a) Pure $\mathrm{ZrO}_{2}$, (b) 10, (c) 20, (d) 30, (e) 40 and (f) 50 . of HPA indicates bulk-like formation of HPA on zirconia. These findings are in good agreement with results of $\mathrm{H}_{4} \mathrm{PMo}_{11} \mathrm{VO}_{40} / \mathrm{SiO}_{2}$ reported by Kanno et al. ${ }^{26}$ Thus, the above results confirm that at lower loadings, the Keggin ion of HPA is well-dispersed on the zirconia support compared to higher loading (50 wt $\%$ ) and bulk HPA (shown in figure 3).

3.1e Temperature-programmed desorption of ammonia: Temperature-programmed desorption (TPD) profiles of ammonia for $\mathrm{H}_{4} \mathrm{PMo}_{11} \mathrm{VO}_{40} / \mathrm{ZrO}_{2}$ with $\mathrm{H}_{4} \mathrm{PMo}_{11} \mathrm{VO}_{40}$ loadings ranging from 10 to $50 \mathrm{wt} \%$ are shown in figure 5 and the amount of $\mathrm{NH}_{3}$ desorbed is reported in table 1 . It can be seen from figure 5 that the desorption peak appearing between $150^{\circ}$ and $300^{\circ} \mathrm{C}$ is attributed to weak acidic sites, the peak noticed between $300^{\circ}$ and $450^{\circ} \mathrm{C}$ is attributed to moderate acidic sites and the peak observed between $450^{\circ}$ and $550^{\circ} \mathrm{C}$ is attributed to strong acidic sites of the catalyst. TPD profiles of lower HPA loading of catalyst showed three desorbed peaks indicating that it has three types of acidic sites (weak, moderate and strong). As the HPA loading increases on zirconia support, weak acidic sites increase gradually from 10$50 \mathrm{wt} \% \mathrm{H}_{4} \mathrm{PMo}_{11} \mathrm{VO}_{40}$ and strong acidic sites decrease with increasing HPA loading. Whereas the moderate acidic sites increase with increase in HPA loading up to $40 \mathrm{wt} \%$, thereafter, it decreases at higher loadings (50 wt \%). Ammonia uptake values of different wt $\%$ HPA on support are summarized in table 1 . It is interesting to see that total acidity of catalyst increases up to $40 \mathrm{wt} \%$ and it is decreases at $50 \mathrm{wt} \%$ HPA loading. Decrease in acidity at higher HPA loading might be due

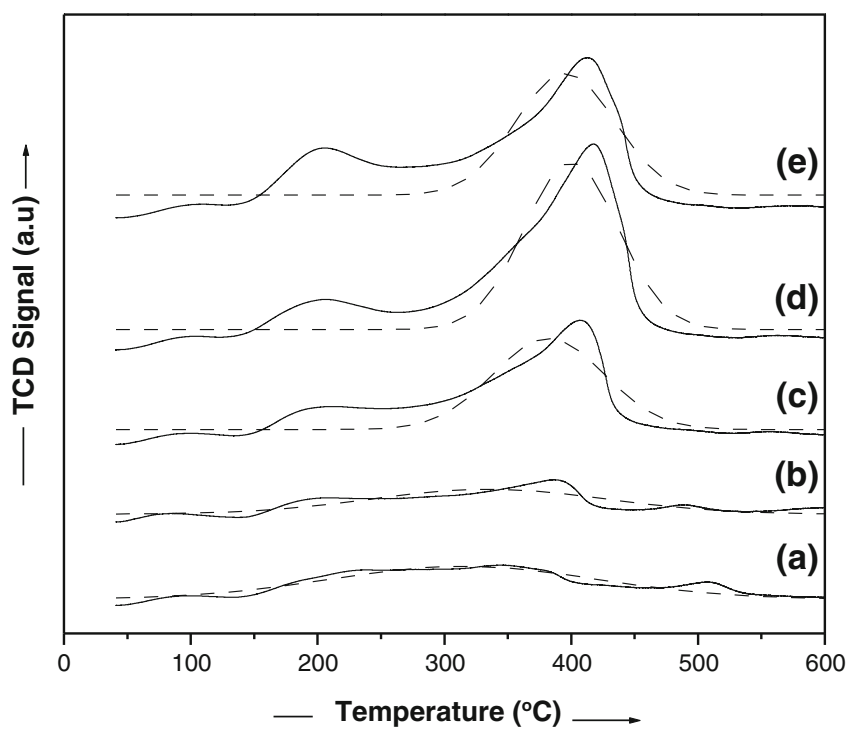

Figure 5. TPD-NH $\mathrm{NH}_{3}$ of various wt $\%$ of $\mathrm{H}_{4} \mathrm{PMo}_{11} \mathrm{VO}_{40} / \mathrm{ZrO}_{2}$ catalysts. (a) 10, (b) 20, (c) 30, (d) 40 and (e) 50 . 
to formation of high crystalline HPA (bulk-like) and it was decomposed at higher loadings leading to decrease in acidity. This was also noticed from the previously described results of FT-IR and Raman studies. There is a considerable amount of strong acidic sites at lower loadings which decreased considerably at higher loadings. TPD of ammonia shows a clear shoulder peak at moderate temperature region and a deconvoluted peak (figure 5). The deconvoluted peak indicates that moderate acidity increases with increase in HPA loading and decreases at higher HPA loadings.

3.1f FT-IR spectroscopy of pyridine adsorption: The nature of acidic sites (Brønsted and Lewis acidic sites) of HPA supported on $\mathrm{ZrO}_{2}$ is also examined by ex situ FT-IR of pyridine-adsorbed samples. Ex situ pyridine FT-IR spectra of various wt $\%$ of $\mathrm{H}_{4} \mathrm{PMo}_{11} \mathrm{VO}_{40}$ on $\mathrm{ZrO}_{2}$ catalysts in the range of $1600-1400 \mathrm{~cm}^{-1}$ are shown in figure 6 . The IR band appearing at $1537 \mathrm{~cm}^{-1}$ is due to Brønsted acidic sites, the IR peak appearing at $1486 \mathrm{~cm}^{-1}$ is assigned to both Brønsted and Lewis $(\mathrm{B}+\mathrm{L})$ acidic sites and the IR band at $1443 \mathrm{~cm}^{-1}$ band is assigned exclusively to Lewis acidic sites. As seen from

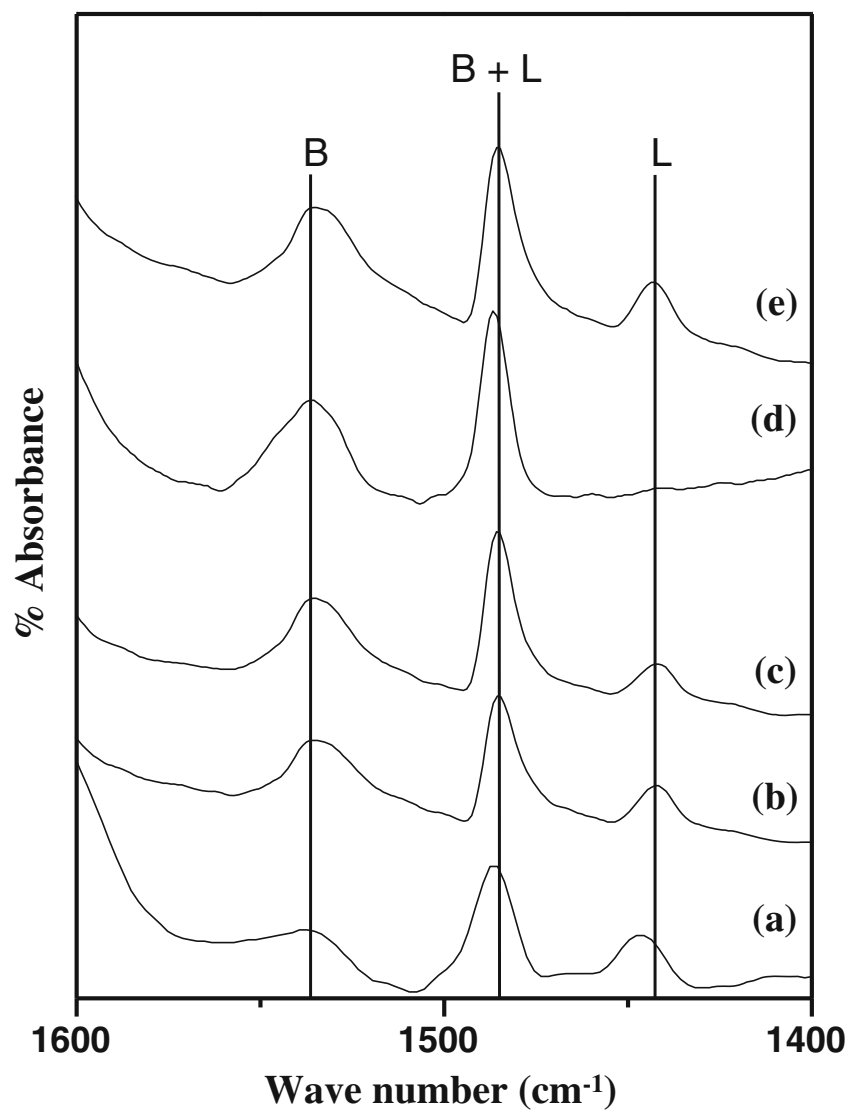

Figure 6. FT-IR spectra of pyridine adsorption of various wt $\%$ of $\mathrm{H}_{4} \mathrm{PMo}_{11} \mathrm{VO}_{40} / \mathrm{ZrO}_{2}$ catalysts. (a) 10 , (b) 20 , (c) 30 , (d) 40 and (e) 50 .

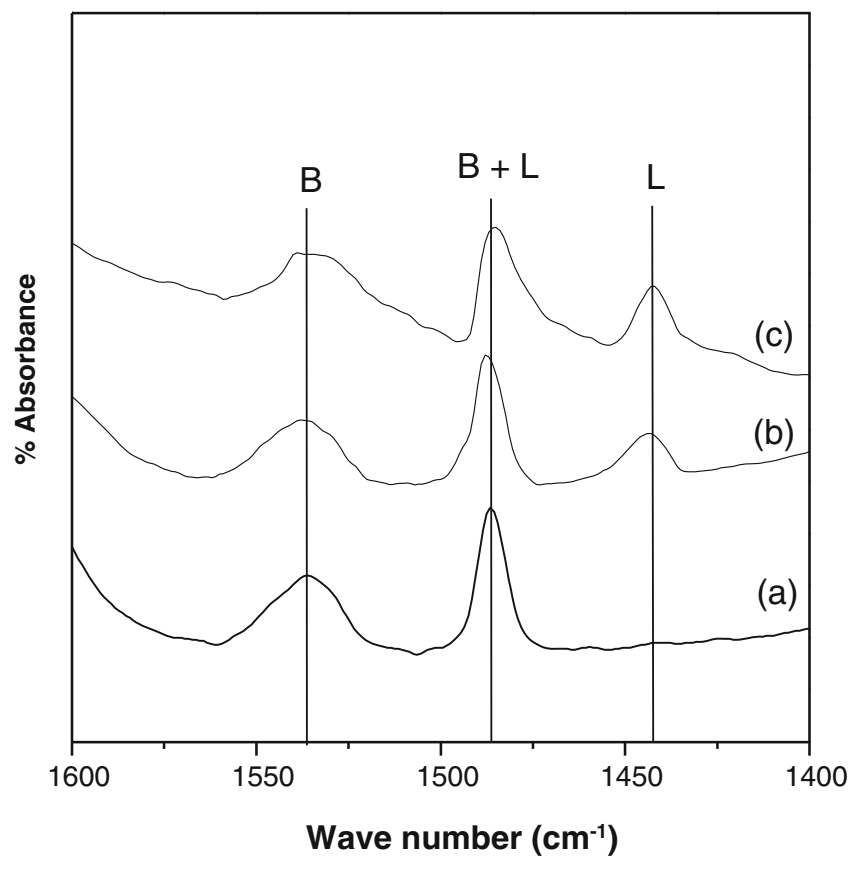

Figure 7. FT-IR spectra of pyridine adsorption of $40 \mathrm{wt} \%$ of $\mathrm{H}_{4} \mathrm{PMo}_{11} \mathrm{VO}_{40}$ on various supports of (a) $\mathrm{ZrO}_{2}$, (b) $\mathrm{TiO}_{2}$ and (c) $\mathrm{Al}_{2} \mathrm{O}_{3}$.

in figure 6 , Brønsted acidity increases with increase in HPA loading up to $40 \mathrm{wt} \%$ and decreases at higher loading. However, Lewis acidity decreases gradually up to $40 \mathrm{wt} \%$ of HPA and increases at higher loadings ( $>40 \mathrm{wt} \%$ catalyst). Intensity of IR bands of both Brønsted and Lewis acidic sites at $1486 \mathrm{~cm}^{-1}$ increases with HPA loading up to $40 \mathrm{wt} \%$ and at higher loading, both the $\mathrm{B}+\mathrm{L}$ acidic sites decrease. These results are in good agreement with previously described acidity measurements by ammonia TPD method.

A comparative study of acidity exhibited by $40 \mathrm{wt} \%$ HPA on different supports $\left(\mathrm{ZrO}_{2}, \mathrm{TiO}_{2}\right.$ and $\left.\mathrm{Al}_{2} \mathrm{O}_{3}\right)$ are examined by ex situ FT-IR spectra of pyridine in the range of $1600-1400 \mathrm{~cm}^{-1}$ (figure 7). As seen in figure 7, intensity of IR peaks for $\mathrm{B}$ and $\mathrm{B}+\mathrm{L}$ acidic sites of $\mathrm{H}_{4} \mathrm{PMo}_{11} \mathrm{VO}_{40} / \mathrm{ZrO}_{2}$ is found to be higher compared to $\mathrm{H}_{4} \mathrm{PMo}_{11} \mathrm{VO}_{40} / \mathrm{TiO}_{2}$ and $\mathrm{H}_{4} \mathrm{PMo}_{11} \mathrm{VO}_{40} / \mathrm{Al}_{2} \mathrm{O}_{3}$. However, intensity of $\mathrm{L}$ acidic sites peak of $\mathrm{H}_{4} \mathrm{PMo}_{11} \mathrm{VO}_{40} / \mathrm{ZrO}_{2}$ is found to be much lower than $\mathrm{H}_{4} \mathrm{PMo}_{11} \mathrm{VO}_{40} / \mathrm{TiO}_{2}$ and $\mathrm{H}_{4} \mathrm{PMo}_{11} \mathrm{VO}_{40} / \mathrm{Al}_{2} \mathrm{O}_{3}$. These results clearly demonstrate that $\mathrm{H}_{4} \mathrm{PMo}_{11} \mathrm{VO}_{40}$ supported on $\mathrm{ZrO}_{2}$ exhibits higher amount of Brønsted acidic sites than HPA supported on $\mathrm{TiO}_{2}, \mathrm{Al}_{2} \mathrm{O}_{3}$.

\subsection{Catalytic activity studies}

3.2a Effect of HPA loading on $\mathrm{ZrO}_{2}$ : Catalytic properties exhibited by various HPA catalysts-supported $\mathrm{ZrO}_{2}$ during vapour phase dehydration of glycerol are shown in figure 8 and the product distribution in table 2. 


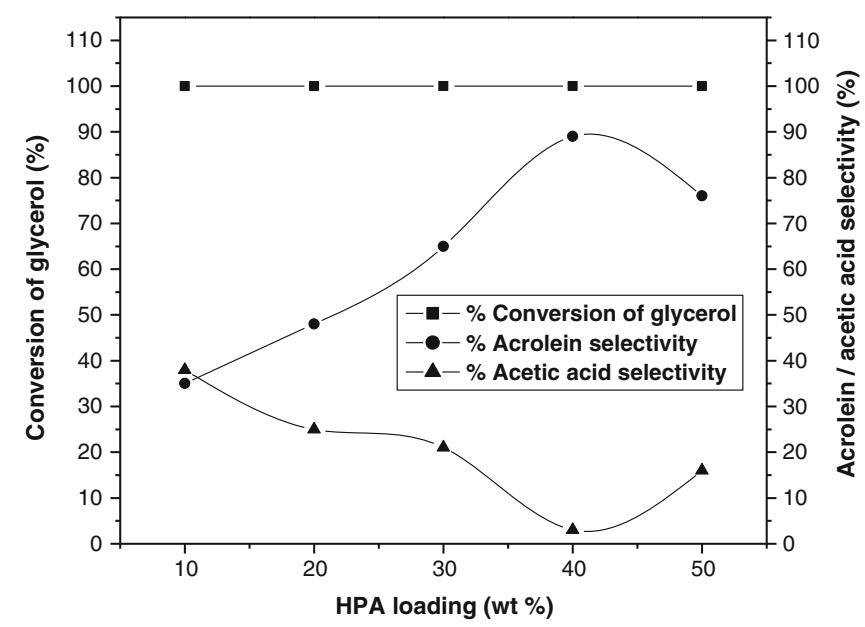

Figure 8. Conversion of aqueous glycerol/acrolein selectivity and wt $\%$ of $\mathrm{H}_{4} \mathrm{PMo}_{1} 1 \mathrm{VO}_{4} \mathrm{O} / \mathrm{ZrO}_{2}$ catalyst at $225^{\circ} \mathrm{C}$.

As seen in figure 8 conversion of glycerol did not appreciably change with HPA loading. It might be due to low concentration of glycerol employed in the feed. However, HPA loading in the catalyst considerably influences acrolein selectivity during glycerol dehydration. It is found that acrolein selectivity increases with increase in HPA loading up to $40 \mathrm{wt} \%$ HPA and decreases at higher HPA loadings. It is interesting to note from the ammonia TPD results that moderate or total acidity increases with increase in HPA loading up to $40 \mathrm{wt} \%$ and further decreases at higher loading. Thus, the above results clearly suggest that acrolein selectivity depends mainly on acidity of the catalyst. The generally accepted reaction for glycerol dehydration is shown in scheme 1 .

According to literature, Brønsted acidic sites are responsible for the formation of acrolein. ${ }^{3}$ As seen in figure 6 that Brønsted acidic sites increase up to $40 \mathrm{wt} \%$ HPA loading and decreases at higher loadings. Acrolein selectivity also increases with HPA loading in a similar way. Therefore, Brønsted acidic sites play an important role in glycerol dehydration to form acrolein selectively. A considerable decrease in selectivity of acrolein is noticed at $50 \mathrm{wt} \%$ HPA due to presence of more number of Lewis acidic sites and also less amount of moderate acidic sites (table 1). The $40 \mathrm{wt} \% \mathrm{HPA} / \mathrm{ZrO}_{2}$ exhibited $89 \%$ acrolein selectivity with complete conversion of glycerol. Acetic acid selectivity decreases with increase in HPA loading up to $40 \mathrm{wt} \%$ of HPA on the support and increases at higher loadings (table 2). This is due to decrease in intensity of $L$ acidic sites peak up to $40 \mathrm{wt} \%$ and increases at higher loading (figure 6). Results of catalytic properties are well-correlated with the nature of acidic sites and also with total acidity of catalysts.

3.2b Effect of reaction temperature: Effect of reaction temperature on dehydration of glycerol was examined over $40 \mathrm{wt} \%$ HPA on zirconia support and the product distribution results are reported in table 3 . As seen from the results in table 3 , selectivity of acrolein and acetic acid varies with reaction temperature. However, conversion of glycerol increases with increase in reaction temperature up to $225^{\circ} \mathrm{C}$ and remains constant at higher temperatures. Presence of vanadium in heteropolyacid prevents deactivation of the catalyst at higher temperatures. This is due to the oxidative ability of vanadium-containing heteropolyacids during the reaction at higher reaction temperature. ${ }^{26,28,31-34,36,39-42}$ As the reaction temperature increases from $200^{\circ}$ to $250^{\circ} \mathrm{C}$, acrolein selectivity increases from $65 \%$ to $89 \%$ and thereafter decreases to $76 \%$, whereas acetic acid selectivity increases from $2 \%$ to $10 \%$ during the reaction. Significant changes in product selectivity are probably due to variation in the nature of acidic sites of

Table 2. Product distribution results of glycerol dehydration over various wt $\%$ of $\mathrm{H}_{4} \mathrm{PMo}_{11} \mathrm{VO}_{40} / \mathrm{ZrO}_{2}$ at $225^{\circ} \mathrm{C}^{\mathrm{x}}$.

\begin{tabular}{lccccc}
\hline & & \multicolumn{3}{c}{ Selectivity (mol\%) } \\
\cline { 3 - 5 } HPA loading on $\mathrm{ZrO}_{2}$ & $\mathrm{Cc}_{\mathrm{gly}}(\%)^{\mathrm{a}}$ & 35 & Ace $^{\mathrm{c}}$ & Aceta $^{\mathrm{d}}$ & Other $^{\mathrm{y}}$ \\
\hline 10 & 100 & 48 & 25 & 10 & 17 \\
20 & 100 & 65 & 21 & 8 & 19 \\
30 & 100 & 89 & 3 & 4 & 4 \\
40 & 100 & 76 & 16 & 2 & 6 \\
50 & 100 & & & 4 & 4 \\
\hline
\end{tabular}

${ }^{\mathrm{x}}$ Results obtained after $4 \mathrm{~h}$. Reaction conditions: catalyst weight $=0.3 \mathrm{~g}$, feed $=0.5 \mathrm{mLh}^{-1}, 10 \mathrm{mLmin}^{-1}$ gas flow rate $\left(\mathrm{N}_{2}\right)$, $10 \mathrm{wt} \%$ aqueous glycerol solution, reaction temperature $=225^{\circ} \mathrm{C}$

${ }^{\mathrm{a}}$ Conversion of glycerol

${ }^{\mathrm{b}}$ Acrolein selectivity

${ }^{c}$ Acetic acid selectivity

${ }^{\mathrm{d}}$ Acetaldehyde selectivity

${ }^{\mathrm{y}}$ Hydroxyacetone, acetone, other products 


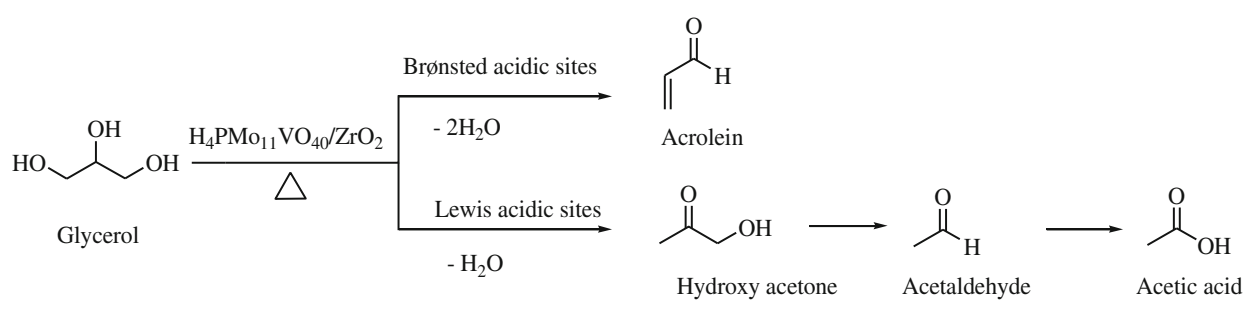

Scheme 1. Glycerol dehydration over $\mathrm{H}_{4} \mathrm{PMo}_{11} \mathrm{VO}_{40} / \mathrm{ZrO}$ catalysts.

vanadium-containing heteropolyacid anion at higher reaction temperature.

3.2c Effect of support: Superior catalytic performance of $\mathrm{HPA} / \mathrm{ZrO}_{2}$ catalysts is also compared with HPA supported on $\mathrm{TiO}_{2}$ and $\mathrm{Al}_{2} \mathrm{O}_{3}$ and the results are reported in table 4. Acrolein selectivity is found to be higher in the case of $\mathrm{ZrO}_{2}$-supported HPA compared to $\mathrm{TiO}_{2}$ and $\mathrm{Al}_{2} \mathrm{O}_{3}$-supported catalysts. Enhancement in the selectivity of acrolein over $\mathrm{HPA} / \mathrm{ZrO}_{2}$ is due to availability of more number of Brønsted acidic sites (figure 7). However, it is observed that acetic acid selectivity is high in the case of $\mathrm{Al}_{2} \mathrm{O}_{3}$-supported catalysts compared to other supports such as $\mathrm{TiO}_{2}$ and $\mathrm{ZrO}_{2}$ (table 4). This might be due to the presence of more number of $\mathrm{L}$ acidic sites in $\mathrm{HPA} / \mathrm{Al}_{2} \mathrm{O}_{3}$ than the other supports as revealed from the FT-IR spectra of pyridine adsorption of $40 \mathrm{wt} \%$ on various supports (figure 7). It is interesting to note that irrespective of support used in dehydration of glycerol, there is no change in the glycerol conversion due to redox nature of vanadiumcontaining HPA..$^{26,28,31-34,36,39-42}$ However, the supports considerably affect selectivity of acrolein and other products. Acrolein selectivity of $\mathrm{H}_{4} \mathrm{PMo}_{11} \mathrm{VO}_{40}$ supported on different supports (table 4) are well-correlated with the results of FT-IR spectra of pyridine-adsorbed samples (figure 7). This results show that catalytic properties depend on the nature of support and interaction between the support and HPA. Thus, $\mathrm{ZrO}_{2}$ as a support exhibits much better catalytic performance than other high surface area $\mathrm{Al}_{2} \mathrm{O}_{3}$ and $\mathrm{TiO}_{2}$ supports indicate that $\mathrm{ZrO}_{2}$ support strongly interacts with primary Keggin unit of HPA than other supports.

3.2d Effect of time on stream: Effect of time on stream on catalytic properties during glycerol dehydration by using $40 \mathrm{wt} \% \mathrm{H}_{4} \mathrm{PMo}_{11} \mathrm{VO}_{40}$ on different supports is shown in figure 9. As seen in figure 9, $\mathrm{HPA} / \mathrm{ZrO}_{2}$ exhibited complete conversion of glycerol with stable activity over a period of $10 \mathrm{~h}$ on stream with high acrolein selectivity ( $10 \mathrm{wt} \%$ aqueous glycerol solution). However, $\mathrm{HPA} / \mathrm{TiO}_{2}$ shows stable activity up to $8 \mathrm{~h}$ and decreases gradually with time on stream. Similarly, acrolein selectivity also decreases with time on stream. In the case of $\mathrm{HPA} / \mathrm{Al}_{2} \mathrm{O}_{3}$, stable activity is noticed only up to $7 \mathrm{~h}$ and further it decreased. Stable activities of $\mathrm{ZrO}_{2}$-supported catalyst compared to other supported catalysts are due to strong interaction between active phase of HPA and zirconia supports than other supports such as alumina and titania. Decrease in glycerol conversion and acrolein selectivity over HPA supported on $\mathrm{Al}_{2} \mathrm{O}_{3}$ and $\mathrm{TiO}_{2}$ is due to significant deactivation of HPA catalyst or decomposition of Keggin ion

Table 3. Product distribution results of glycerol dehydration over $40 \mathrm{wt} \% \mathrm{H}_{4} \mathrm{PMo}_{11} \mathrm{VO}_{40} / \mathrm{ZrO}_{2}$ catalyst at $200^{\circ}-250^{\circ} \mathrm{C}^{\mathrm{X}}$.

\begin{tabular}{lccccc}
\hline & & \multicolumn{3}{c}{ Selectivity (mol\%) } \\
\cline { 3 - 5 } Reaction temperature $\left({ }^{\circ} \mathrm{C}\right)$ & $\mathrm{C}_{\mathrm{gly}}(\%)^{\mathrm{a}}$ & $\mathrm{Ac}^{\mathrm{b}}$ & $\mathrm{Ace}^{\mathrm{c}}$ & Aceta $^{\mathrm{d}}$ & Other $^{\mathrm{y}}$ \\
\hline 200 & 91 & 65 & 2 & 12 & 21 \\
225 & 100 & 89 & 3 & 4 & 4 \\
250 & 100 & 78 & 10 & 2 & 10 \\
\hline
\end{tabular}

${ }^{\mathrm{x}}$ Results obtained after $4 \mathrm{~h}$. Reaction conditions: catalyst weight $=0.3 \mathrm{~g}$, feed $=0.5 \mathrm{mLh}^{-1}, 10 \mathrm{mLmin}^{-1} \mathrm{gas}_{\text {flow rate }}\left(\mathrm{N}_{2}\right)$, $10 \mathrm{wt} \%$ aqueous glycerol solution, reaction temperature $=200^{\circ}-250^{\circ} \mathrm{C}$

${ }^{\mathrm{a}}$ Conversion of glycerol

${ }^{\mathrm{b}}$ Acrolein selectivity

${ }^{c}$ Acetic acid selectivity

${ }^{\mathrm{d}}$ Acetaldehyde selectivity

${ }^{\mathrm{y}}$ Hydroxyacetone, acetone products 
Table 4. Product distribution results of glycerol dehydration over $40 \mathrm{wt} \% \mathrm{H}_{4} \mathrm{PMo}_{11} \mathrm{VO}_{40}$ on different support catalyst at $225^{\circ} \mathrm{C}^{\mathrm{X}}$.

\begin{tabular}{lcccccc}
\hline & & \multicolumn{3}{c}{ Selectivity (mol\%) } \\
\cline { 5 - 7 } HPA on support & BET surface area $\left(\mathrm{m}^{2} / \mathrm{g}\right)$ & $\mathrm{C}_{\mathrm{gly}}(\%)^{\mathrm{a}}$ & & $\mathrm{Ac}^{\mathrm{b}}$ & $\mathrm{Aceta}^{\mathrm{d}}$ & Other $^{\mathrm{y}}$ \\
\hline $\mathrm{ZrO}_{2}$ & 19 & 100 & 89 & 3 & 4 & 4 \\
$\mathrm{TiO}_{2}$ & 15 & 100 & 76 & 18 & 3 & 3 \\
$\mathrm{Al}_{2} \mathrm{O}_{3}$ & 146 & 100 & 53 & 28 & 5 & 13
\end{tabular}

${ }^{\mathrm{x}}$ Results obtained after $4 \mathrm{~h}$. Reaction conditions: catalyst weight $=0.3 \mathrm{~g}$, feed $=0.5 \mathrm{mLh}^{-1}, 10 \mathrm{mLmin}^{-1} \mathrm{gas}_{\text {flow }}$ rate $\left(\mathrm{N}_{2}\right)$, $10 \mathrm{wt} \%$ aqueous glycerol solution, reaction temperature $=225^{\circ} \mathrm{C}$

${ }^{\mathrm{a}}$ Conversion of glycerol

${ }^{\mathrm{b}}$ Acrolein selectivity

${ }^{\mathrm{c} A c e t i c}$ acid selectivity

${ }^{\mathrm{d}}$ Acetaldehyde selectivity

${ }^{\mathrm{y}}$ Hydroxyacetone, acetone, other products

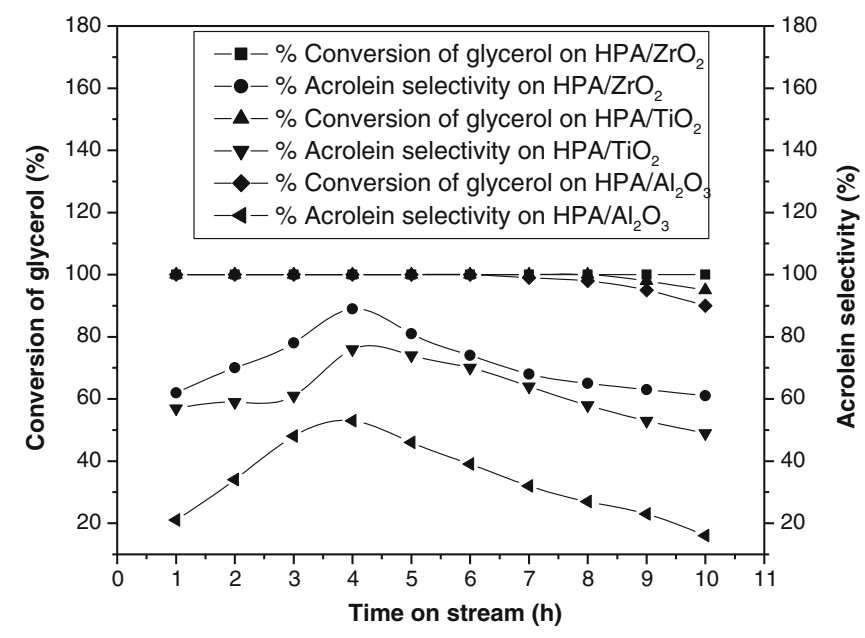

Figure 9. Time on stream studies of $40 \mathrm{wt} \% \mathrm{HPA}$ on $\mathrm{ZrO}_{2}$, $\mathrm{TiO}_{2}$ and $\mathrm{Al}_{2} \mathrm{O}_{3}$ support at $225^{\circ} \mathrm{C}$.

structure of HPA on the support during the course of the reaction.

\section{Conclusion}

Vanadium-containing phosphomolybdic acid catalysts supported on $\mathrm{ZrO}_{2}$ polymorphs are found to be highly active and selective for dehydration of glycerol to acrolein compared to HPA supported on $\mathrm{Al}_{2} \mathrm{O}_{3}$ and $\mathrm{TiO}_{2}$. This is mainly due to the presence of highly dispersed $\mathrm{H}_{4} \mathrm{PMo}_{11} \mathrm{VO}_{40}$ Keggin structure on $\mathrm{ZrO}_{2}$ support leading to strong interaction between primary structure of Keggin ion and $\mathrm{ZrO}_{2}$ support. XRD results suggest that HPA is present in a highly dispersed state at lower loadings. FT-IR and Raman spectroscopy confirm that the characteristic Keggin ion of HPA remains intact with the support. TPD of ammonia results confirms that
$40 \mathrm{wt} \%$ HPA loading possesses higher amount of moderate acidic sites and also high total acidity compared to other HPA loadings of the catalysts. Ex situ FT-IR of pyridine adsorption results suggests that $40 \mathrm{wt} \%$ HPA has higher amount of Brønsted acidity than other loadings. Amount of Brønsted acidity is also higher in HPA supported on $\mathrm{ZrO}_{2}$ than $\mathrm{Al}_{2} \mathrm{O}_{3}$ and $\mathrm{TiO}_{2}$-supported catalysts. Acrolein selectivity during vapour phase dehydration of glycerol is well-correlated with the moderate or total acidity and Brønsted acidity of the catalysts. Furthermore, this study reveals optimum composition of $\mathrm{H}_{4} \mathrm{PMo}_{11} \mathrm{VO}_{40}$ over zirconia catalyst (40 wt $\%$ ) for obtaining good catalytic performance in dehydration of glycerol to acrolein at $225^{\circ} \mathrm{C}$ under atmospheric pressure (mild reaction conditions).

\section{Acknowledgements}

The authors thank the Director, IICT, Hyderabad. BV thanks the Council of Scientific and Industrial Research (CSIR), New Delhi for the award of Senior Research Fellowship. This work is supported by CSIR, New Delhi under the Network projects of XII -5 year plan (Indus Magic-WP3).

\section{References}

1. Zhou C H, Beltramini J N, Fana Y X and Lu G Q 2008 Chem. Soc. Rev. 37527

2. Jia C J, Liu Y, Schmidt W, Lu A H and Schüth F 2010 J. Catal. 26971

3. Katryniok B, Paul S, Baca V B, Rey P and Dumeignil F 2010 Green. Chem. 122079

4. Pagliaro M, Ciriminna R, Kimura H, Rossi M and Pina C D 2007 Ang. Chem. Int. Ed. 464434

5. Behr A, Eilting J, Irawadi K, Leschinski J and Lindner F 2008 Green. Chem. 1013 
6. Kim Y T, Jung K D and Park E D 2011 Appl. Catal. B: Environ. 107177

7. Tao L Z, Chai S H, Zuo Y, Zheng W T, Liang Y and Xu B Q 2010 Catal. Today 158310

8. Atia H, Armbruster U and Martin A 2011 Appl. Catal. A: Gen. 393331

9. Deleplanque J, Dubois J L, Devaux J F and Ueda W 2010 Catal. Today 157351

10. Ulgen A and Hoelderich W F 2011 Appl. Catal. A: Gen. 40034

11. Cavani F, Guidetti S, Marinelli L, Piccinini M, Ghedini E and Signoretto M 2010 Appl. Catal. B: Environ. 100 197

12. Pathak K, Reddy K M, Bakhshi N N and Dalai A K 2010 Appl. Catal. A: Gen. 372224

13. Suprun W, Lutecki M, Gläser R and Papp H 2011 J. Mol. Catal. A: Chem. 342-34391

14. Alhanash A, Kozhevnikova E F and Kozhevnikov I V 2010 Appl. Catal. A: Gen. 37811

15. Wang F, Dubois J L and Ueda W 2010 Appl. Catal. A: Gen. 37625

16. Garbay P L, Millet J M M, Loridant S, Baca V B and Rey P 2011 J. Catal. 28068

17. Yoda E and Ootawa A 2009 Appl. Catal. A: Gen. 36066

18. Gu Y, Cui N, Yu Q, Li C and Cui Q 2012 Appl. Catal. A: Gen. 429-430 9

19. Sancho C G, Tost R M, Robles J M, González J S, López A J and Torres P M 2012 Appl. Catal. A: Gen. 433-434 179

20. Wang F, Dubois J L and Ueda W 2009 J. Catal. 268260

21. Chai S H, Wang H P, Liang Y and Xu B Q 2008 Green. Chem. 101087

22. Chary K V R, Ramesh K, Naresh D, Rao P V R, Rao A $\mathrm{R}$ and Rao V V 2009 Catal. Today 141187

23. Chary K V R, Ramesh K, Vidyasagar G and Rao V V 2003 J. Mol. Catal. A: Gen. 198195
24. Chai S H, Wang H P, Liang Y and Xu B Q 2009 Appl. Catal. A: Gen. 353213

25. Devassy B M and Halligudi S B 2005 J. Catal. 236313

26. Kanno M, Yasukawa T, Ninomiya W, Ooyachi $\mathrm{K}$ and Kamiya Y 2010 J. Catal. 2731

27. Barteau K P, Lyons J E, Song I K and Barteau M A 2006 Top. Catal. 4155

28. Song I K and Barteau M A 2004 J. Mol. Catal. A: Chem. 212229

29. Weber R S 1994 J. Phys. Chem. 982999

30. Baghernejad B, Heravi M M, Oskooie H A and Bamoharram F F 2012 Bull. Chem. Soc. Ethiop. 26145

31. Kanno M, Miura Y K, Yasukawa T, Hasegawa T, Ninomiya W, Ooyachi K, Imai $H$, Tatsumi $\mathrm{T}$ and Kamiya Y 2011 Catal. Commun. 1359

32. Benadji S, Eloy P, Léonard A, Su B L, Bachari K, Rabia C and Gaigneaux E M 2010 Micro. Meso. Mater. 130 103

33. Romanelli G P, Villabrille P I, Cáceres C V, Vázquez P $\mathrm{G}$ and Tundo P 2011 Catal. Commun. 12726

34. Erfle S, Armbruster U, Bentrup U, Martin A and Brückner A 2011 Appl. Catal. A: Gen. 391102

35. Kaba M S, Barteau M A, Lee W Y and Song I K 2000 Appl. Catal. A: Gen. 194-195129

36. Zhang J, Tang Y, Li G and Hu C 2005 Appl. Catal. A: Gen. 278251

37. Ilkenhans T, Herzag B, Braun T and Schlogl R 1995 J. Catal. 153275

38. Shi L, Tin C K and Wong B N 1999 J. Mater. Sci. 34 3367

39. Collins F M, Lucy A R and Sharp C 1997 J. Mol. Catal. A: Chem. 117397

40. Barteau M A, Lyons J E and Song I K 2003 J. Catal. 216 236

41. Liu H and Iglesia E 2003 J. Phys. Chem. B107 10840

42. Choi J H, Park D R, Park S and Song I K 2011 Catal. Lett. 141826 